\title{
Blue light inactivation of the enveloped RNA virus Phi6
}

\author{
Petra Vatter, Katharina Hoenes and Martin Hessling ${ }^{*}$ (]
}

\begin{abstract}
Objective: Ultraviolet radiation is known for its antimicrobial properties but unfortunately, it could also harm humans. Currently, disinfection techniques against SARS-CoV-2 are being sought that can be applied on air and surfaces and which do not pose a relevant thread to humans. In this study, the bacteriophage phi6, which like SARSCoV-2 is an enveloped RNA virus, is irradiated with visible blue light at a wavelength of $455 \mathrm{~nm}$.

Results: For the first time worldwide, the antiviral properties of blue light around $455 \mathrm{~nm}$ can be demonstrated. With a dose of $7200 \mathrm{~J} / \mathrm{cm}^{2}$, the concentration of this enveloped RNA virus can be successfully reduced by more than three orders of magnitude. The inactivation mechanism is still unknown, but the sensitivity ratio of phi6 towards blue and violet light hints towards an involvement of photosensitizers of the host cells. Own studies on coronaviruses cannot be executed, but the results support speculations about blue-susceptibility of coronaviruses, which might allow to employ blue light for infection prevention or even therapeutic applications.
\end{abstract}

Keywords: Phi6, Photoinactivation, Blue light, Coronavirus, SARS-CoV-2

\section{Introduction}

Since December 2019, a new coronavirus capable of causing the severe pulmonary infection CoVid-19 has been spreading worldwide, and is therefore referred to as SARS-CoV-2 (severe acute respiratory syndrome coronavirus). As the number of infected and fatalities continues to rise, with more than 100 million infections and more than 2 million fatalities at the beginning of February 2021 [1], disinfection options are being sought to contain the further spread of the virus. Chemical disinfectants, heat, and ultraviolet radiation are successful against the virus [2-6], but can also be harmful to humans.

In recent years, visible blue and violet light has been employed to inactivate bacteria and fungi without particularly harming human cells [7-16]. The mechanism of action, which is similar for prokaryotic and eukaryotic cells, is based on endogenous photosensitizers naturally

*Correspondence: Martin.Hessling@thu.de

Institute of Medical Engineering and Mechatronics, Ulm University of Applied Sciences, Ulm, Germany occurring in these microorganisms, such as porphyrins or flavins [17-23]. These photosensitizers absorb visible light of specific wavelengths and generate so-called reactive oxygen species (ROS) in the presence of oxygen, including ${ }^{1} \mathrm{O}_{2}, \mathrm{O}_{2}{ }^{*}{ }^{*}, \mathrm{H}_{2} \mathrm{O}_{2}$ and $\mathrm{HO}^{*}$, which attack and kill the cells from inside.

Initial studies reveal that violet light with a wavelength of $405 \mathrm{~nm}$ has an inactivating effect on viruses [24-26]. This is even true for the bacteriophage phi6, which, like the SARS-CoV-2 virus, is an enveloped RNA virus [27]. Therefore, it is hoped that SARS-CoV-2 is also sensitive to violet light.

Studies on the effect of blue, non-violet light on any viruses do not exist so far, although this wavelength range (450-470 nm) has advantages over violet light. It is even less harmful to human cells [9-11, 28] and exhibits a higher penetration depth into human tissue, which might lead to future local therapies that try to fight coronaviruses in the human body, if coronaviruses exhibit a sensitivity to visible light. At least, some local blue or violet illumination applications have been investigated for the 


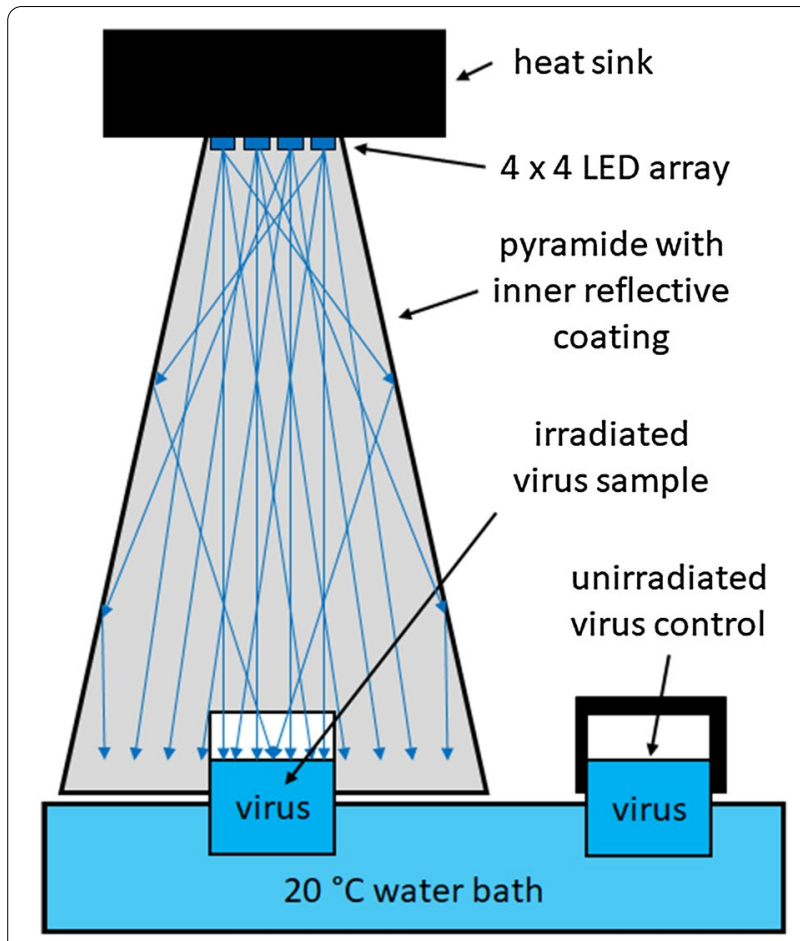

Fig. 1 Scheme of the illumination setup

treatment of bacterial or fungal infections, e. g. as therapy for acne [29,30], Helicobacter pylori infections in the stomach [31], vaginal infections [32] and for the prevention of ventilator-associated pneumonia [33].
Unfortunately, we are not allowed to work with coronaviruses in our laboratory. Therefore, in the study presented here, experiments on the inactivation of phi6-as a non-pathogenic coronavirus surrogate-are performed with $455 \mathrm{~nm}$ blue light and compared to the results of a previous $405 \mathrm{~nm}$ investigation [27].

\section{Main text \\ Method Irradiation setup}

The description of the irradiation setup is presented schematically in Fig. 1. Two glass beakers containing a virus-containing solution are kept at approximately 20 ${ }^{\circ} \mathrm{C}$ using a temperature-controlled water bath. One of the samples is irradiated from above by an array of 16 $(4 \times 4) 455 \mathrm{~nm}$ LEDs of RP-Technik GmbH (Rodgau, Germany). A hollow pyramid with reflective coating at the inside provides a homogeneous irradiance of up to $50 \mathrm{~mW} / \mathrm{cm}^{2}$ in the sample plane at a distance of $28 \mathrm{~cm}$. The emission spectrum of the employed $455 \mathrm{~nm}$ LEDs is given in Fig. 2, together with the emission spectrum of the $405 \mathrm{~nm}$ LED employed by Vatter et al. in a former study [27] and the absorption of known bacterial photosensitizers. This illustrates that at least for bacteria $405 \mathrm{~nm}$ and blue $455 \mathrm{~nm}$ irradiation involve different photosensitizers. The second beaker glass is shielded from light and serves as a control.

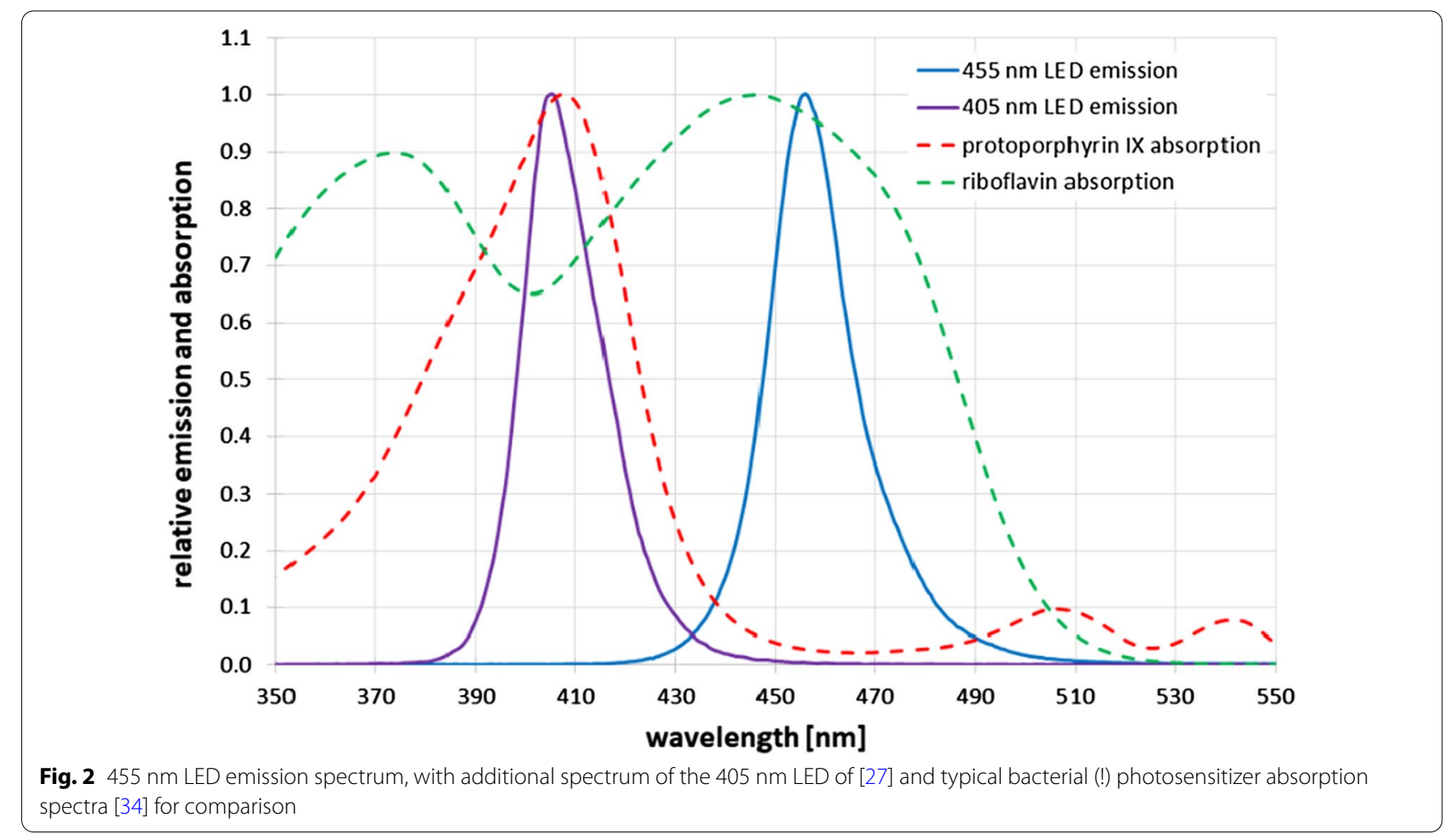




\section{Microbiological experiments}

Test virus is the bacteriophage phi6 (DSM 21518), which is multiplied by its host bacterium Pseudomonas syringae (DSM 21482). For the experiments, approximately $1.5 \times 10^{7}$ viruses or plaque forming units (PFU) per $\mathrm{ml}$ of a phosphate buffered saline (PBS) solution are prepared. Samples are drawn for $0 \mathrm{~h}, 8 \mathrm{~h}, 16 \mathrm{~h}$, $24 \mathrm{~h}, 32 \mathrm{~h}$ and $40 \mathrm{~h}$ of irradiation. At the end of each irradiation experiment, a double agar overlay plaque assay is performed: small volumes of the irradiated and non-irradiated virus samples are first mixed with Pseudomanas syringae and then poured as a liquid agar layer onto solid agar plates. In the absence of replicable viruses, bacteria will multiply in the agar and provide detectable turbidity. However, existing phi6 can infect and lyse bacteria. This creates holes/plaques in the agar turbidity from which the concentration of replicable phi6 in the samples and thus the disinfection effect of the $455 \mathrm{~nm}$ radiation can be calculated $[27,35]$.

\section{Results}

At least three technical replicates were performed of each individual irradiation dose up to $7200 \mathrm{~J} / \mathrm{cm}^{2}$ over a period of up to $40 \mathrm{~h}$ and each series of measurements was executed three times. Typical results for an non-irradiated and an irradiated virus sample with the double agar overlay plaque assay are illustrated in Fig. 3. The difference in the number of plaques-and therefore virusesbetween non-irradiated and irradiated sample is evident. Figure $3 \mathrm{~b}$ reveals the quantitative results. The phi6 concentrations in the non-irradiated samples hardly changed during the $40 \mathrm{~h}$ duration of the experiment, but in the irradiated samples the virus concentration was successfully reduced by more than three orders of magnitude after $7200 \mathrm{~J} / \mathrm{cm}^{2}$ at $455 \mathrm{~nm}$. The necessary log-reduction dose is about $2130 \mathrm{~J} / \mathrm{cm}^{2}$ at $455 \mathrm{~nm}$-compared to a logreduction dose of approximately $430 \mathrm{~J} / \mathrm{cm}^{2}$ at $405 \mathrm{~nm}$ according to Vatter et al. [27].

\section{Discussion}

For the first time, it could be demonstrated that the enveloped RNA virus phi6 is sensitive to visible blue light with a wavelength of $455 \mathrm{~nm}$. The sensitivity is about 5 times lower than its $405 \mathrm{~nm}$ sensitivity, which was observed in a previous study [27]. This ratio is a typical sensitivity ratio known for pseudomonads and bacteria in general between these wavelengths [36, 37].

Nevertheless, the virus sensitivity to visible light is unexpected. In bacteria the presence of endogenous
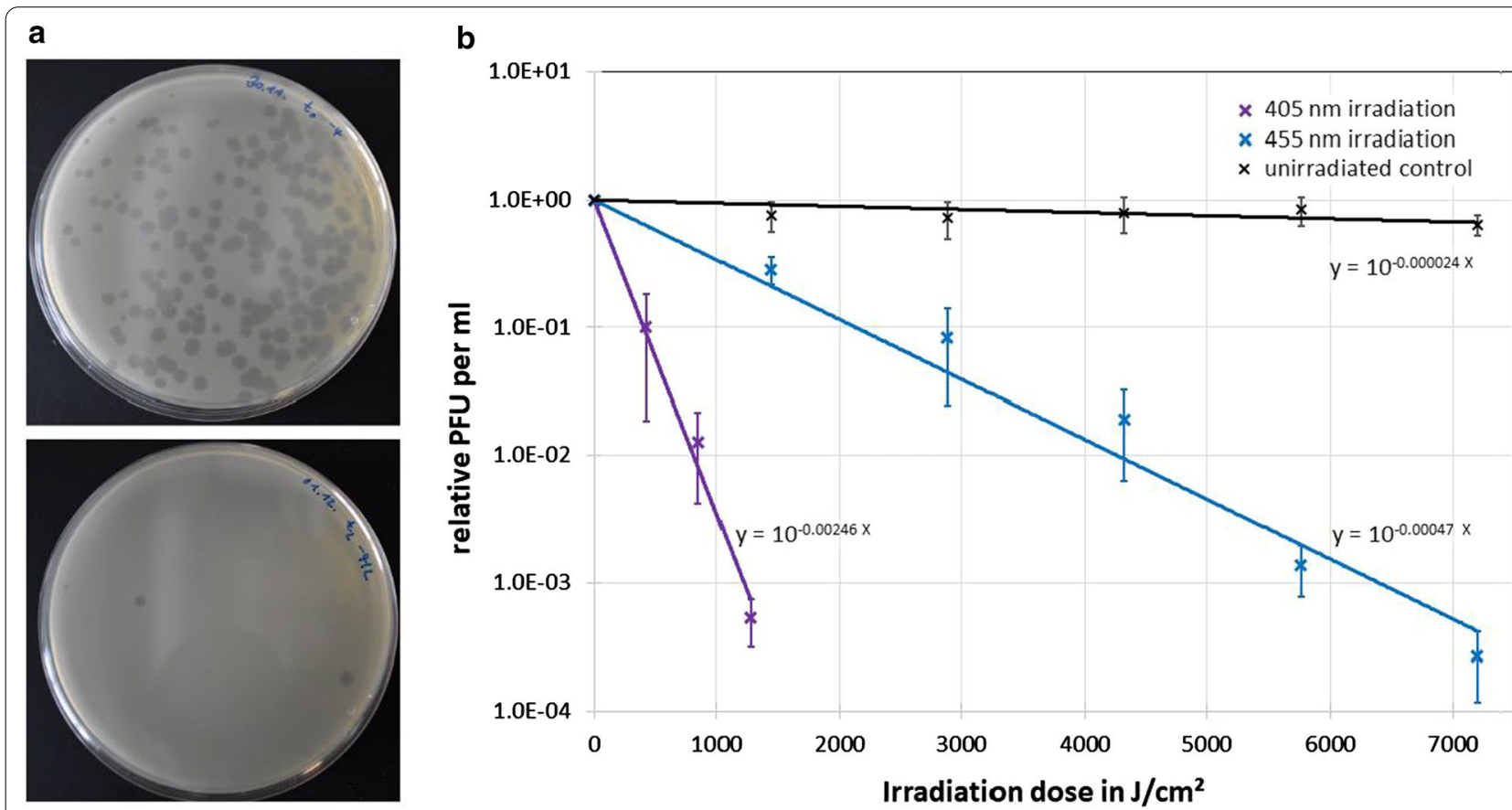

Fig. 3 Results of the $455 \mathrm{~nm}$ irradiation of phi6 samples. a Example photographs of virus solution on agar plates. After $24 \mathrm{~h}$ the viruses have created visible plaques in the bacterial lawn. Top: non-irradiated sample, bottom: same sample after $2880 \mathrm{~J} / \mathrm{cm}^{2}$ at $455 \mathrm{~nm}$. b Evolution of phi6 concentration in plaque forming units (PFU) per $\mathrm{ml}$ as a function of the $455 \mathrm{~nm}$ irradiation dose. The former $405 \mathrm{~nm}$ results [27] are added for comparison. Each value represents the average of at least three independent experiments and the error bars depict the standard deviation of these single measurements 
photosensitizers like porphyrins and flavins is well known, because they are results of the bacterial metabolism. The virus however exhibits no metabolism and should not need or produce such photosensitizers. Even if it contains one photosensitizer this should be effective either at $405 \mathrm{~nm}$ or $455 \mathrm{~nm}$-but not at both wavelengths. The fact that the virus concentration is reduced at both wavelengths and the sensitivity ratio between 455 and $405 \mathrm{~nm}$, which is similar to the above mentioned typical bacterial ratios, gives room for the speculation that the virus unintentionally takes along the bacterial photosensitizers of its host (Pseudomomas syringae) when it assembles its envelope.

\section{Conclusion}

Whether the more important SARS-CoV-2 also contains photosensitizers and exhibits photoinactivation sensitivity towards blue or visible light is unknown so far, but there are hints that this coronavirus might at least contain porphyrins [38], which would possibly result in a sensitivity towards $405 \mathrm{~nm}$ irradiation. The advantage of a $455 \mathrm{~nm}$ light sensitivity could be the higher penetration depth of blue light in human tissue compared to violet light in a-speculative-future antiviral therapy.

\section{Limitations}

Coronaviruses and phi6 are both enveloped RNA viruses, and phi6 has often been applied as coronavirus surrogate in the past, but so far there is no prove for any sensitivity of coronaviruses towards blue or violet light. Unfortunately, our lab does not have the required security clearance for coronavirus experiments.

\begin{abstract}
Abbreviations
LED: Light emitting diode; SARS-CoV-2: Severe acute respiratory syndrome coronavirus 2; CoVid 19: Covid coronavirus disease 2019; RNA: Ribonucleic acid; ROS: Reactive oxygen species; LED: Light emitting diode; DSM: Deutsche Sammlung von Mikroorganismen und Zellkulturen; PBS: Phosphate buffered saline.
\end{abstract}

\section{Acknowledgements}

Not applicable.

\section{Authors' contributions}

$\mathrm{PV}, \mathrm{KH}$ and $\mathrm{MH}$ designed the experiments. PV carried out the experiments and analyzed the data. $\mathrm{PV}$ and $\mathrm{MH}$ drafted the manuscript. $\mathrm{PV}, \mathrm{KH}$ and $\mathrm{MH}$ revised the final manuscript. All authors read and approved the final manuscript.

\section{Funding}

Open Access funding enabled and organized by Projekt DEAL. The 455 nm irradiation experiments were financially supported by RP-Technik $\mathrm{GmbH}$ (Rodgau, Germany). The article processing charge was funded by the Baden-Württemberg Ministry of Science, Research and Culture and the UIm University of Applied Sciences in the funding program Open Access Publishing.
Availability of data and materials

All data generated or analyzed during this study are included in this published article.

\section{Declarations}

Ethics approval and consent to participate

Not applicable.

\section{Consent for publication}

Not applicable.

\section{Competing interests}

The authors declare that there is no conflict of interest.

Received: 10 March 2021 Accepted: 6 May 2021

Published online: 17 May 2021

\section{References}

1. Coronavirus Resource Center. COVID-19 dashboard: (Global Map). 2021 https://coronavirus.jhu.edu/map.html. Accessed 6 Feb 2021.

2. Hessling $M$, Hönes $K$, Vatter $P$, Lingenfelder $C$. Ultraviolet irradiation doses for coronavirus inactivation - review and analysis of coronavirus photoinactivation studies. GMS Hyg Infect Control. 2020;15:Doc8. https://doi.org/ 10.3205/dgkh000343.

3. Kampf G, Todt D, Pfaender S, Steinmann E. Persistence of coronaviruses on inanimate surfaces and their inactivation with biocidal agents. J Hosp Infect. 2020;104:246-51. https://doi.org/10.1016/j.jhin.2020.01.022.

4. Kampf G, Voss A, Scheithauer S. Inactivation of coronaviruses by heat. J Hosp Infect. 2020. https://doi.org/10.1016/j.jhin.2020.03.025.

5. Kratzel A, Todt D, V'kovski P, Steiner S, Gultom M, Thao TTN, et al. Inactivation of severe acute respiratory syndrome coronavirus 2 by WHOrecommended hand rub formulations and alcohols. Emerg Infect Dis. 2020;26:1592-5. https://doi.org/10.3201/eid2607.200915.

6. Hessling M, Hoenes K, Lingenfelder C. Selection of parameters for thermal coronavirus inactivation-a data-based recommendation. GMS Hyg Infect Control. 2020. https://doi.org/10.3205/dgkh000351.

7. McDonald RS, Gupta S, Maclean M, Ramakrishnan P, Anderson JG, Macgregor SJ, et al. $405 \mathrm{~nm}$ Light exposure of osteoblasts and inactivation of bacterial isolates from arthroplasty patients: potential for new disinfection applications? Eur Cell Mater. 2013;25:204-14.

8. Wang T, Dong J, Yin H, Zhang G. Blue light therapy to treat candida vaginitis with comparisons of three wavelengths: an in vitro study. Lasers Med Sci. 2020. https://doi.org/10.1007/s10103-019-02928-9.

9. Liebmann J, Born M, Kolb-Bachofen V. Blue-light irradiation regulates proliferation and differentiation in human skin cells. J Invest Dermatol. 2010;130:259-69. https://doi.org/10.1038/jid.2009.194.

10. Bumah W, Masson-Meyers DS, Awosika O, Zacharias S, Enwemeka CS The viability of human cells irradiated with 470-nm light at various radiant energies in vitro. Lasers Med Sci. 2021. https://doi.org/10.1007/ s10103-021-03250-z.

11. Makdoumi K, Hedin M, Bäckman A. Different photodynamic effects of blue light with and without riboflavin on methicillin-resistant Staphylococcus aureus (MRSA) and human keratinocytes in vitro. Lasers Med Sci. 2019:34:1799-805. https://doi.org/10.1007/s10103-019-02774-9.

12. Ramakrishnan P, Maclean M, MacGregor SJ, Anderson JG, Grant MH. Differential sensitivity of osteoblasts and bacterial pathogens to 405-nm light highlighting potential for decontamination applications in orthopedic surgery. J Biomed Opt. 2014;19:105001. https://doi.org/10.1117/1.JBO. 19.10.105001.

13. Dai T, Gupta A, Huang Y-Y, Yin R, Murray CK, Vrahas MS, et al. Blue light rescues mice from potentially fatal Pseudomonas aeruginosa burn infection: efficacy, safety, and mechanism of action. Antimicrob Agents Chemother. 2013;57:1238-45. https://doi.org/10.1128/AAC.01652-12.

14. Dai T, Gupta A, Huang Y-Y, Sherwood ME, Murray CK, Vrahas MS, et al. Blue light eliminates community-acquired methicillin-resistant Staphylococcus aureus in infected mouse skin abrasions. Photomed Laser Surg. 2013;31:531-8. https://doi.org/10.1089/pho.2012.3365 
15. Zhang Y, Zhu Y, Gupta A, Huang Y, Murray CK, Vrahas MS, et al. Antimicrobial blue light therapy for multidrug-resistant Acinetobacter baumannii infection in a mouse burn model: implications for prophylaxis and treatment of combat-related wound infections. J Infect Dis. 2014;209:1963-71. https://doi.org/10.1093/infdis/jit842.

16. Zhang Y, Zhu Y, Chen J, Wang Y, Sherwood ME, Murray CK, et al. Antimicrobial blue light inactivation of Candida albicans: in vitro and in vivo studies. Virulence. 2016;7:536-45. https://doi.org/10.1080/21505594.2016. 1155015.

17. Ashkenazi H, Malik Z, Harth Y, Nitzan Y. Eradication of Propionibacterium acnes by its endogenic porphyrins after illumination with high intensity blue light. FEMS Immunol Med Microbiol. 2003;35:17-24. https://doi.org/ 10.1111/j.1574-695X.2003.tb00644.x.

18. Guffey JS, Wilborn J. In vitro bactericidal effects of 405-nm and 470-nm blue light. Photomed Laser Surg. 2006;24:684-8. https://doi.org/10.1089/ pho.2006.24.684.

19. Maclean M, MacGregor SJ, Anderson JG, Woolsey G. High-intensity narrow-spectrum light inactivation and wavelength sensitivity of Staphylococcus aureus. FEMS Microbiol Lett. 2008;285:227-32. https://doi.org/10. 1111/j.1574-6968.2008.01233.x.

20. Feuerstein O, Ginsburg I, Dayan E, Veler D, Weiss El. Mechanism of visible light phototoxicity on Porphyromonas gingivalis and Fusobacterium nucleatum. Photochem Photobiol. 2005;81:1186-9. https://doi.org/10. 1562/2005-04-06-RA-477.

21. Amin RM, Bhayana B, Hamblin MR, Dai T. Antimicrobial blue light inactivation of Pseudomonas aeruginosa by photo-excitation of endogenous porphyrins: in vitro and in vivo studies. Lasers Surg Med. 2016;48:562-8. https://doi.org/10.1002/Ism.22474.

22. Plavskii VY, Mikulich AV, Tretyakova Al, Leusenka IA, Plavskaya LG, Kazyuchits OA, et al. Porphyrins and flavins as endogenous acceptors of optical radiation of blue spectral region determining photoinactivation of microbial cells. J Photochem Photobiol B. 2018;183:172-83. https://doi. org/10.1016/j.jphotobiol.2018.04.021.

23. Cieplik F, Spath A, Leibl C, Gollmer A, Regensburger J, Tabenski L, et al. Blue light kills Aggregatibacter actinomycetemcomitans due to its endogenous photosensitizers. Clin Oral Investig. 2014;18:1763-9. https://doi. org/10.1007/s00784-013-1151-8.

24. Richardson TB, Porter CD. Inactivation of murine leukaemia virus by exposure to visible light. Virology. 2005;341:321-9. https://doi.org/10.1016/j. virol.2005.07.025.

25. Tomb RM, Maclean M, Coia JE, Graham E, McDonald M, Atreya CD, et al. New proof-of-concept in viral inactivation: virucidal efficacy of 405 $\mathrm{nm}$ light against feline calicivirus as a model for norovirus decontamination. Food Environ Virol. 2016;9:159-67. https://doi.org/10.1007/ s12560-016-9275-z.

26. Tomb RM, Maclean M, Herron PR, Hoskisson PA, MacGregor SJ, Anderson JG. Inactivation of Streptomyces phage C31 by $405 \mathrm{~nm}$ light: requirement for exogenous photosensitizers? Bacteriophage. 2014;4:e32129. https:// doi.org/10.4161/bact.32129.
27. Vatter P, Hoenes K, Hessling M. Photoinactivation of the coronavirus surrogate phi6 by visible light. Photochem Photobiol. 2021;97:122-5. https://doi.org/10.1111/php.13352.

28. Opländer C, Hidding S, Werners FB, Born M, Pallua N, Suschek CV. Effects of blue light irradiation on human dermal fibroblasts. J Photochem Photobiol B. 2011;103:118-25. https://doi.org/10.1016/j.jphotobiol.2011. 02.018.

29. Elman M, Slatkine $M$, Harth $Y$. The effective treatment of acne vulgaris by a high-intensity, narrow band $405-420 \mathrm{~nm}$ light source. J Cosmet Laser Ther. 2003;5:111-7.

30. Kawada A, Aragane Y, Kameyama H, Sangen Y, Tezuka T. Acne phototherapy with a high-intensity, enhanced, narrow-band, blue light source: an open study and in vitro investigation. J Dermatol Sci. 2002;30:129-35.

31. Ganz RA, Viveiros J, Ahmad A, Ahmadi A, Khalil A, Tolkoff MJ, et al. Helicobacter pylori in patients can be killed by visible light. Lasers Surg Med. 2005;36:260-5. https://doi.org/10.1002/Ism.20161.

32. Robatto M, Pavie MC, Garcia I, Menezes MP, Bastos M, Leite HJD, et al. Ultraviolet A/blue light-emitting diode therapy for vulvovaginal candidiasis: a case presentation. Lasers Med Sci. 2019;34:1819-27. https://doi. org/10.1007/s10103-019-02782-9.

33. Sicks B, Hoenes K, Spellerberg B, Hessling M. Blue LEDs in endotracheal tubes may prevent ventilator associated pneumonia. Photobiomodul Photomed Laser Surg. 2020. https://doi.org/10.1089/pho.2020.4842.

34. Hessling M, Wenzel U, Meurle T, Spellerberg B, Hönes K. Photoinactivation results of Enterococcus moraviensis with blue and violet light suggest the involvement of an unconsidered photosensitizer. Biochem Biophys Res Commun. 2020;533:813-7. https://doi.org/10.1016/j.bbrc.2020.09.091.

35. Kropinski AM, Mazzocco A, Waddell TE, Lingohr E, Johnson RP. Enumeration of bacteriophages by double agar overlay plaque assay. In: Walker JM, Clokie MRJ, Kropinski AM, editors. Bacteriophages. Totowa: Humana Press; 2009. p. 69-76. https://doi.org/10.1007/978-1-60327-164-6_7.

36. Hessling M, Spellerberg B, Hoenes K. Photoinactivation of bacteria by endogenous photosensitizers and exposure to visible light of different wavelengths - a review on existing data. FEMS Microbiol Lett. 2016;364:fnw270. https://doi.org/10.1093/femsle/fnw270.

37. Hoenes K, Bauer R, Meurle T, Spellerberg B, Hessling M. Inactivation effect of violet and blue light on ESKAPE pathogens and closely related non-pathogenic bacterial species - a promising tool against antibioticsensitive and antibiotic-resistant microorganisms. Front Microbiol. 2020;11:612367. https://doi.org/10.3389/fmicb.2020.612367.

38. Wenzhong L, Hualan L. COVID-19: attacks the 1-beta chain of hemoglobin and captures the porphyrin to inhibit human heme metabolism: Preprint. ChemRxiv; 2020. https://doi.org/10.26434/chemrxiv.11938173. v9.

\section{Publisher's Note}

Springer Nature remains neutral with regard to jurisdictional claims in published maps and institutional affiliations.
Ready to submit your research? Choose BMC and benefit from:

- fast, convenient online submission

- thorough peer review by experienced researchers in your field

- rapid publication on acceptance

- support for research data, including large and complex data types

- gold Open Access which fosters wider collaboration and increased citations

- maximum visibility for your research: over $100 \mathrm{M}$ website views per year

At BMC, research is always in progress.

Learn more biomedcentral.com/submissions 